\title{
Historiographical Imagination about Savagery and Barbaric Stages of Primitive Human Species
}

\section{Pramod Kumar Srivastava*}

Retired Professor and Emeritus Fellow (UGC-2015-17), Department of Western History, University of Lucknow, Lucknow, India Email: srivastavapk2010@gmail.com,munnu1900@yahoo.com, srivastavapkumar@icloud.com

How to cite this paper: Srivastava, P. K. (2021). Historiographical Imagination about Savagery and Barbaric Stages of Primitive Human Species. Advances in Anthropology, 11, 280-296.

https://doi.org/10.4236/aa.2021.114016

Received: September 21, 2021

Accepted: November 5, 2021

Published: November 8, 2021

Copyright (๑) 2021 by author(s) and Scientific Research Publishing Inc. This work is licensed under the Creative Commons Attribution International License (CC BY 4.0).

http://creativecommons.org/licenses/by/4.0/

Open Access

\begin{abstract}
Indeed, Imagination could not work as a valid method for understanding prehistory and pre-historical processes as subjective or objective source. Yet historiographical imagination is only available inductive method for writing prehistory and pre-historical processes. Out of the few significant inherent natural features of the mind of Homo sapiens, a product of evolution memory, imagination, creativity, and power of comprehending complex natural processes are against preceding minds of primitive human species. The naturally evolved primitive human mind also learnt art of making fire, bow and arrows, pottery, stone implements, adobe-brick houses and later plantation by irrigation. The two historical facts transmuted the existing basic instincts making them primitive humans, other than preceding species of humans. 1) The phenomenon of inter-tribal battles, becoming order of the day during savagery because of sneaking clandestinely or openly, from other human tribes women, children, and domestic animals provided four kinds of human in a victorious tribe, "victor male", "victor female", "subjugated male" and "subjugated female", which transfigured the existing sexual behavior in a tribe; and 2) the other phenomenon of "surplus labor" available only to males
\end{abstract}

${ }^{\star}$ His significant contributions are: 1) Filipino Tribes and United States Penetration, The Eastern Anthropologist, Vol.37, No.3, July-Sept. 1984, 2) Resistance and repression in India: the hunger strike at Andaman cellular jail, 1933, Crime, Histoire \& Socie'te'/Crime, History and Societies, vol. 7, no. 2, 2003; 3) Book Review-The Long Partition and the making of South Asia: Refugees, Boundaries, Histories by Vazira Fazila-Yacoobali Zamindar, New York: Columbia University Press, 2007, The Oral History Review, vol. 37, No. 2, 2010, published by Oxford University Press on behalf of the Oral History Association, USA. 4) Female Infanticide in $19^{\text {th }}$ Century India: A Genocide? Advances in Historical Studies, 2014, 3, 269-284; 5) Nationalism Imagined? Hidden Impacts of the Uprising of 1857, South Asia Research, vol. 38(3), 2018; and 6) Pramod Kumar, Mahatma Betrayed, National Publishing House, New Delhi, 2005, 2007. WorldCat Identities: Pramod Kumar 1952-Classifications: HV9794.P67.303.61095488. 
because of "surplus pregnancy" of females finally became the instigator of distinction between female and male, which in due course during the various stages of savagery and barbarism became susceptible for the origin of patriarchy. The present paper deals with the historiographical imagination as an inductive method for understanding responses of primitive human mind during various stages of savagery and barbarism.

\section{Keywords}

Memory, Historiographical Imagination, Patriarchy, Inter-Tribal Battle, Savagery, Barbarism, Surplus Labor, Surplus Pregnancy

\section{The Problem}

The history of discovering the factors of the origin of female subjugation is not less than a century old. Innumerable historians, anthropologists and philosophers have attempted through their scholarly research works and serious analytical deliberations to unearth the answer of this tortuous question lying in the mist of ahistorical past. Though immense scholarly works have already been published on the subject, none of them have given consideration to certain significant phenomenon, which must have taken place while modern human species was transmuted into Homo sapiens, with a uniquely developed mind, not yet achieved by its preceding species. All such phenomenon took place much earlier than the making of a family-Consanguine family, the Punaluan family or else. The direction of all such studies based upon the origin of families has been confined to progressive development from pre-historic promiscuous human society to monogamous society through polyandrous society to pairing marriage, group marriage, and polygamous society. The foundation of such unilateral studies is based upon the inference that matriarchy is a certainty in a promiscuous and polyandrous society while a monogamous society is destined to become patriarchal. In her quest to examine the claims and evidence for the existence of a matriarchy, Paula Webster wrote, "We assumed that since patriarchy meant the dominance of men as a class over women as a class, then matriarchy would be defined as the mirror opposite: a society in which women as a class had power and authority over men. ${ }^{1}$ We did not expect that hierarchy itself would have been eliminated, but that if someone had to be "on the top", it would be women. This was the social organization we expected to find described by J.J. Bachofen in his Das Mutterrecht and by Frederick Engels in the Origin of the family, Private Property, and the State (1884)," (Webster, 1975: p. 142) yet Engels propounded step by step progressive development to a monogamous society, destined to be a patriarchal society. His following para is worth meditating:

"Thus as wealth increased, it, on the one hand, gave the man a more im-

${ }^{1}$ The use of the word class is not used in the Marxian sense but as simply a grouping based upon gender. 
portant status in the family than the woman, and, on the other hand, created a stimulus to utilize this strengthened position in order to overthrow the traditional order of inheritance in favor of his children. But this was impossible as long as descent according to mother right prevailed.” (Engels, 1948: p. 56)

It is a well-established fact that whenever there comes a new knowledge of any kind, it first strengthens the existing powerful class of a society. If there was a matrilineal society, the increase of wealth would have further strengthened the line of matrilineal descent, instead it overthrew it. This is quite unnatural raising the doubt if there was any such revolution. However, it is praiseworthy that author honestly accepts that as to how and when this revolution was affected among the civilized peoples we know nothing. It falls entirely within prehistoric times."

Lila Leibowitz's article Perspective on the Evolution of Sex Differences, Sally Slocom's article Woman the Gatherer: Male Bias in Anthropology, Kathleen Gough's article The Origin of the family and many other articles in Rayna R. Reiter (Ed), Toward an Anthropology of Women (Reiter, 1975), delve more around anthropological researches and debates around male and female power structure than around pre-historical phenomenon taking place during savagery and barbaric periods of antiquity; like all the authors, scholars, historians and philosophers of nineteenth century following Bachofen centered around growth and development of different kinds of families leading to monogamous marriages based upon researches of different human societies scattered around the globe. Moreover, their findings depended mostly upon deductive methodology marginalizing the fact that patriarchy developed almost everywhere in due course of time. The cosmopolitanism of universal patriarchy must have progressively developed everywhere instead of parochial kinds of development of male-female sexual relations, in the complete absence of mutual communication among them during prehistoric times.

\section{Historiographical Imagination and Memory as Tools of Past}

To find out the answers to above problems including the cosmopolitanism of universal patriarchy and historical institution of marriages necessarily requires a universal kind of inductive reasoning, hereinafter, designated, defined and analyzed as historical imagination, like memory served as ahistorical source for Herodotus, and Thucydides etc. for the purpose of historical understanding of the phenomenon rationally evolved even during the ages of savagery and barbarism as imagined by Morgan (Morgan, 1877).

1) The human Mind: The distinctive feature of human mind evolved as different than other living creatures include feature of memorizing all kinds of natural facts, independent of time and space, and historical facts, not independent of time and space; features of comprehending complex processes of nature, im- 
agination, and of creativity or innovation or producer of innate ideas or forgetfulness. Out of all these five human qualities of humans (there may be many more not yet known) developed because of natural evolution only few of the five features of human mind dominate the rest of the other features, which determines the basic distinctive quality of a human. For example, a human mind with a very powerful memory is devoid of very powerful feature of imagination, comprehension or creativity. This is also true for all the five features of human mind that only one of them dominates the rest of the four features. Human mind is also capable of producing ideas or impulses, as power of thinking is completely independent of all known realities of nature or history. The impulses or ideas of human mind are also capable of travelling in both directions past and future. When it travels in past it is historiographical imagination otherwise it is simply pure imagination.

2) Imagination and historiographical imagination: Imagination is a natural fact independent of time and space but historiographical imagination is a historical fact not independent of time and space. All kinds of arts including painting and sculptor, literature and music, and other creativities or innovations are products of the pure imagination, which are natural facts independent of time and space. However, impulses or ideas of human mind when travel in past it produces historiographical imagination, which is not independent of time and space, which might be designated as historical fact.

3) Past and dimensions of past: All history is past but all past is not history. In fact, past is not monolithic but contains at-least four dimensions, ahistorical past, historical past, past in individual perception and past in collective memory. The unrecorded "past" or ahistorical "past" includes all acts of human since antiquity or since growth of thinking human, which is neither recorded nor survives in memory of human race yet had played a role in making "collective knowledge" and "collective faith" of the particular human societies of the planet earth at particular time scales.

The recorded "past" or historical "past" since human race throughout the globe left evidences in the form of "cave and rock paintings" or written manuscripts, printed documents, coins, monuments, relics and ruins requires interpretation of those "historical facts" by the historians. The third dimension of "past" or "past in perception", acquired or inherited genetically, which remains imprinted in the conscious, sub-conscious and unconscious memory of individual human determines the responses of particular individual towards day-to-day realities. The "past" in a "collective memory" of a particular society is the fourth dimension, which reflects in social responses of the given society. The "collective memory" of a particular society is created out of the cumulative collective memories of the given society since time immemorial composed of both recorded "past" and unrecorded "past". Since historian is also a part of the particular society of his own his mind is not also beyond the influence of "collective memory" of his own society. The making of a "true" historian depends upon his own 
deliberate and strenuous efforts in cleaning his mind from the influences of "collective memory" of his own society, especially about "collective memories" grown around race, kinship, religion, nation, caste, sexuality, matrimony and language.

4) Past is only real: Out of total three dimensions of time, past, present and future, only past is real. Other two dimensions, present and future are merely imaginary. Only past exists as concrete, real, solid and material, which alone could be studied, documented and re-produced. As against this, both present and future, both of which are imaginary and non-existent could not be studied, documented or re-produced. "The present", location of which is between past and future is non-existent as its length is not ascertained, whether it is a day long, or hour long or fraction of second long. In fact, at each moment, the past is under creation. The moment an act is performed it becomes past, without encountering the dimension of so called "the present."

5) Memory as a tool: On the basis of memory of past of an individual a oral historian may recreate past in his own mind, which will serve as source for history in addition with historical facts available with findings of other historians, documents, charters, archeological evidences etc of the nearest past. Since historical source is unavailable and impossible to ascertain about remotest past or ahistorical past (defined ahead) including ages of savagery and barbarism there remains historiographical imagination alone to write history of remotest past mostly about the ages of savagery and barbarism.

Out of five known features of human mind only memory has been used as an objective source of history by innumerable historians of past. The Greek historians Herodotus (Herodotus, 2003) the "father of history", who wrote Histories (c.484-c.420) and Thucydides (c. 460-c.400), (Thucydides, 1972) who wrote Peloponnesian wars, applied the method of interviewing for collection of their historical facts, as Collingwood mentioned: (Collingwood, 2015: p. 25) Three thousand years ago, scribes of Zhou dynasty in China collected the sayings of the people for the use of court historians. The Spanish chroniclers of sixteenth century relied on oral sources to reconstruct the history of the inhabitants-from the Aztecs to the Incas-of the Americas conquered by Europeans. Until seventeenth century such histories written on the basis of eyewitnesses remained the only primary source for the coming generations of historians. In 1773 Samuel Johnson argued that "a man by talking with those of different sides, who were actors in it and putting down all that he hears, may in time collect the materials of a good narrative." He also emphasis "all history was at first oral." Voltaire (1694-1778), the great philosopher and author of The Age of Louis XIV, wrote that he had questioned "old couriers, servants, great lords, and others." The historian of French revolution of 1789, Jules Michelet (7 vols. Paris, 1847-53) contrasted the official documents with the memories of "peasants, townsfolk, old men, women, even children; which you can hear if you enter an evening into a village tavern." William Gordon interviewed the participants of the American War of Inde- 
pendence and Hubert Howe Bancroft wrote his seven Volume History of California (1884-90) on the basis of interviews of nineteenth century Mexican military governors, civilian officials and first American settlers. (Ritchie, 2003: pp. 19-20)

Certainly, exactly like memory, the historical imagination, another significant trait of human mind could also be used for understanding and writing history of ahistorical past.

\section{Historiographical Imagination as a Tool about Humans during Savagery and Barbarism}

The modern man or Homo Sapience, as known in scientific terminology, is an animal with an additional essential characteristics of natural power of thinking, a natural evolutionary advancement upon the mind of preceding species of Homo sapiens, and also an additional characteristics of producing material (Physical) items in accordance with immaterial ideas, produced in uniquely developed mind, because of erect bipedalism - "the advantages of freeing the hands for food carrying or for tool use. Freeing the hands allowed more manipulation of the environment in the direction of tools for gathering and hunting food. Through a hand-eye-brain feedback process, coordination, efficiency, and skill were increased." (Sally Slocum, 1975: pp. 40-41) Homo sapiens has also an additional natural craving of mind over two natural cravings of preceding species, the craving for sustenance and natural craving for sex for natural instinct of reproduction and sexual pleasure; common somehow to all living creatures including vegetation and animals. The natural craving for sex, a natural instinct, was not just a product of natural instinct of reproduction alone but was also stimulated by hormonal chemistry of sexual pleasure obtained by the sexual acts resulting ultimately into pregnancy of females besides all other sexual acts providing instant sexual pleasure-touching, kissing and acts of seducing and cajoling etc. All these three kinds of natural cravings of Homo sapiens natural craving for sustenance, natural craving for sex and natural production of mind-ideas or impulses or power of thinking - jointly remained the cradle into which modern civilization of the modern man came into existence through the stages of Savagery to Barbarism (Morgan, 1877: pp. 9-10) and till then accumulated historical experiences of human mind vide its power of memorizing a fact. All other living creatures, with only two kinds of natural cravings-craving for sustenance and craving for sex were naturally deficient in growing any other kind of civilization than that naturally bestowed upon them, because of deficiency of natural power of the mind of Homo sapiens. L.S. Morgan wrote:

"The Lower Status of Savagery commenced with the infancy of the human race, and ...ended with the acquisition of a fish subsistence and of a knowledge of the use of fire. Mankind were then, living in their original restricted habitat, and subsisting upon fruits and nuts. The commencement of articulate speech belongs to this period...The Middle Status of Savagery (It) 
commenced with the acquisition of a fish subsistence and a knowledge of the use of fire, and ended with the invention of the bow and arrow...The Upper Status of Savagery (It) commenced with the invention of the bow and arrow, and ended with the invention of the art of pottery. The Lower Status of Barbarism. The invention or practice of the art of pottery, all things considered, is probably, the most effective and conclusive test that can be selected to fix a boundary line, necessarily arbitrary, between savagery and barbarism. ... In the Eastern hemisphere, the domestication of animals, and the Western, the cultivation of maize and plants by irrigation, together with the use of adobe-brick and stone in house building have been selected as sufficient evidence of progress to work a transition out of the Lower and into the Middle Status of barbarism. The Middle Status of Barbarism (It) commenced with the domestication of animals in the Eastern hemisphere, and in the Western with cultivation by irrigation and with the use of adobe-brick and stone in architecture, as shown. The Upper Status of Barbarism (It) commenced with the manufacture of Iron, and ended with the invention of a phonetic alphabet, and the use of writing in literary composition.” (Morgan, 1877: pp. 9-11)

Relying at least upon this part of the researches of Morgan and the above long paragraph, it may conclusively be established that inter-tribal battles and issues of "surplus labor" and "surplus pregnancy" emerged during the very primitive ages of savagery and barbarism.

The phenomenon of "inter-tribal battles" and "issues of surplus labor and surplus pregnancy", served as the factors because of which patriarchy originated during primitive ages of savagery and barbarism.

Such food gatherer societies of humans during various stages of savagery-lower, middle and upper and barbarism had only two kinds of natural wealth-females and children in communal possession. There was no private property, no private female or no private children. All those were common property of the nomadic tribes, remnant of which custom continued even up to the commencement of upper stage of savagery at many places. The institution of marriage was yet to be invented, which was a historical institution in place of natural.

To satiate the natural craving for sustenance, the natural quality of mind, capable of producing immaterial ideas, invented "the acquisition of a fish subsistence and of the use of fire", during lower stage of savagery, "the period of infancy of the human race. Mankind were then living in their original restricted habitat, and subsisting upon fruits and nuts." (Morgan, 1877: pp. 9-10). As per Morgan mankind learnt domestication of animals during middle status of barbarism. Mankind domesticated milk-producing animals also for milk sustenance as artificial sustenance exactly like fish sustenance. The mankind was then living in their original nature of satiating also its natural craving for sex, without any restriction like all other animals including preceding species of Homo sapiens.

Johann Jacob Bachofen (1815-1887), an author of Mother Right advanced the 
proposition:

"1) [T] hat in the beginning humanity lived in a state of sexual promiscuity, which the author unhappily designates as "hetaerism"; 2) that such promiscuity excludes all certainty as regards paternity, that lineage, therefore, could be reckoned only through the female line according to mother right and that originally this was the case among all the people of antiquity; 3 ) that consequently women, who as mothers, were the only definitely ascertainable parents of the younger generation, were treated with a high degree of consideration and respect, which according to Bachofen's conception, was enhanced to the complete rule of women (gynecocracy);....." (Engels, 1948: p. 10)

Such promiscuity continued upto the life of Herodotus (484-421 B.C.) who witnessed presence of this custom in Massagetae. (Herodotus, 1954: p. 89) "As to their customs: every man has a wife, but all wives are used promiscuously." (Herodotus, 1954: p. 94) In other words, such custom prevailed in Greece during the life span of Herodotus, when marriages had already been originated and in practice in Greece and adjoining neighboring areas. Custom of marriage in fact originated only after the knowledge and practice of agriculture was begun to be known and practiced.

The lower stage of Savagery ended with the acquisition of fish subsistence, though human biologically was a food gatherer depending entirely upon fruits and nuts. However, the scarcity of fruits or problems arising out of finding sufficient fruits for subsistence forced them to catch fish for survival. Similarly, acquisition of animal milk required for human survival initiated domestication of pet animals during lower stage of barbarism.

During upper stage of barbarism each human tribe throughout the globe had a universal kind of constitution having male and female humans in addition with their male and female siblings and milk producing pet animals. Here, it is also to be pondered whether humans relied first upon fish sustenance or used milk of pet animals for their sustenance. The human tribes scattered throughout the globe used milk of pet animals like cows, buffaloes, goats, sheep, camels and yaks as available in their vicinities. The pet animals were the third communal property beside women and children of the human tribes, which promoted a human tribe to loot them from neighboring human tribes.

Until middle status of barbarism or emergence of the knowledge and practice of plantation, all Human tribes scattered throughout the globe vide great migrations, were threatened by the invading tribes for the purpose of looting females and children to enhance their numbers and pet animals for milk sustenance. Females were snatched for reproduction, children for increasing their numbers and pet animals for using their milk sustenance. Such tribal raids became a universal occasion for frequent inter-tribal battles. Each inter-tribal battle resulted into a victorious tribe having victorious male, victorious female, subjugated male, and subjugated female besides other battle booty. 


\section{Historiographical Imagination about Inter-Tribal Battles and Origin of Patriarchy and Slavery}

End of each inter-tribal battle found a victor tribe, which was constituted of two kinds of males-victor male (master man) and male of defeated tribe (slave man); and two kinds of females-female of victor tribe (master female) and female of defeated tribe (subjugated female). Both male and female of defeated tribes were destined to become slave of both the victor male and the victor female.

Males of victorious tribe became master of both females of victorious tribe and females of defeated tribe. Males of victorious tribe enjoyed pleasure of having right of sex over both of them. The only difference was that while children from victorious females became masters from slave females became slaves. This was the beginning of the origin of patriarchal society and also of the phenomenon of slavery throughout the human settlements.

As against this, female of victorious tribe (master female) had only rightful option of having sexual intercourse available with males of her own victorious tribe alone. Having sexual relation with slave male was degrading for her in the eyes of victorious tribe. Later, such relations first became unwanted, then prohibited and gradually punishable offence for both female of victorious tribe and slave male, after the origin of state and primitive religions. ${ }^{2}$ The existing freedom of sex between males and females of their choices was therefore begun curtailed for females of victorious tribe. This was the beginning of prohibition for females to choose male of their own choice for sex.

On the other side, the females of defeated tribe or slave females had no right to refuge either of males-master or slave to have sex with him. Being female of defeated tribe or a slave female she could not say "no" to her master or any male of victorious tribe. Though there was no concept of right to say "no" during those times but it was her natural right enjoyed by her since age of savagery or since origin of her experience of her own mind. Now she was denied her natural right to say "no". This was also the beginning of the crime of "rape". ${ }^{3}$ The first mention of rape also appears in The Histories written by Herodotus, who wrote:

"Neither the Athenians nor any other Greeks had house-slaves in those days, so their own daughters used to go for the water; and whenever they did so, the Pelasgians, regardless of decency or respect, used to rape them."

(Herodotus, 1954: p. 410)

\footnotetext{
${ }^{2}$ The phenomenon commenced during inter-tribal or inter-racial battles between victorious Aryan and subjugated non-Aryan still continues between descendants of Aryan and non-Aryan Indian tribes or races, even after thousands of intervening centuries.

${ }^{3}$ There were also two kinds of discriminatory laws against offence of rape committed by victorious Aryan and subjugated non-Aryans in cases of victorious Aryan victim woman and non-Aryan subjugated victim woman in India. According to Brihaspati (a law giver of 100-300B.C.) "[I] $\mathrm{n}$ the case of forceful intercourse with woman of similar caste total property should be snatched, genital organs including testicles should be cut, forced to ride on ass; but if caste of victim is lower than offender, the above punishment should be half; but if caste of women is higher than the man, then the man should be given capital punishment." [Translated from Hindi to English by this author]. Dr. Pandurang Vaman Kane, 1965: p. 830].
} 
Axiomatic as it is the crime of rape was prevailing in certain human societies during the days of Herodotus.

Now, if it became a taboo for master female to choose a sexual partner for her from slaves; a slave female lost her natural right to say "no" to a male of victorious tribe. Now, female in general lost her natural right to choose her sexual partner or deny will of her masters. Undergoing such historical phenomenon an almost innovated culture of sexual exploitation of female started taking shape in which she was denied all natural kinds of sexual freedoms available to her till then as females of primitive human societies.

Slave male could not have sex with female of victorious tribe at any cost. Therefore, there was no possibility of successor from a master female and a slave male. Because of such historicity following kind of society had started taking shape until end of barbaric period and beginning of civilization. Almost all the existing tribes coming out of the phenomenon of inter-tribal battles were constituted of victorious males and victorious females along with male and female slaves having innovated kind of sexual behaviorism based upon universal promiscuity prevailing in the preceding generations.

\section{Historiographical Imagination about Agriculture and Origin of Marriages, Slavery and Imperialism}

The institution of marriage was yet to be invented. The selective promiscuity was still the sexual order of the day yet the overall sexual behavior among the victorious tribes was thoroughly transforming following each inter-tribal battle, or inter-racial battle, or battles among nomadic and settled human societies.

However, there are many stories told by the anthropologists and sociologists about origin of the historical institution of marriage. According to an Anglo-American anthropological theory,

"The men hunted wild animals and feasted on their meat. Their brains became very large because they had to cooperate with each other in the hunt. They stood upright, made tools, built fires, and invented language. Their cave art was very fine...But the women were very poor. They were tied down by childbearing, and they did not know how to get food for themselves or their babies. They did not know how to protect themselves from predators. They did not know, too, how to make tools, produce art, and build lodges or campfires to keep themselves warm." (Stephanie Coontz, 2005: p. 35)

Moreover, as against this, the upper stage of barbarism and the dawn of the lower stage of civilization witnessed both the knowledge and practice of agriculture, and plantation in Western hemisphere. The knowledge and practice of agriculture and plantation transformed the basic nature of migratory human tribes to stop migration for the purpose of the search of fruits for sustenance. Knowledge and practice of agriculture and plantation during middle status of 
barbarism enhanced the value of land and land also became a kind of significant property besides females, children and milk-producing domesticated animals. Now an innovated kind of land acquisition commenced leading to an idea of imperialism after birth of primitive state and primitive religion. Grabbing more and more agricultural land commenced becoming order of the day, ultimately creating the phenomenon of imperialism in state affairs.

Land as productive asset raised the question of its inheritance after the demise of its owner. In fact, the maternity was factual but paternity was by opinion alone. Since the custom of promiscuity was prevailing during the upper stage of barbarism determination of rightful successor of both male and female from amongst the actual sons and daughters was impossible. Therefore, an idea of marriage originated in the primitive human mind of the middle status of barbarism, siblings of whom alone were considered rightful successors of the owner of productive land. Preference for male successors over female successors was a later development following origin of patriarchy. The customary law originated since inter-tribal battles giving preference to victor male and victor female in comparison to subjugated male and female, even continued after the birth of marriages and incorporated into primitive religious laws. ${ }^{4}$

\section{Historiographical Imagination about Surplus Labor and Surplus Pregnancy}

Subjugation of females commenced in the very critical period of middle stage of barbaric period. It was surplus labour of male, which promoted prehistoric division of labour in groups of primitive humans. The birth and practice of bow and arrow, and making of pottery, and adobe-brick and stone house required essential working hours to be performed by both male and female. After managing food for the day, male had more extra-surplus labor than female. Male used this extra-surplus labor in performing different kinds of activities including making bow and arrows, hunting, art of pottery, carving stone implements and so and so including sexual intercourse. "The surplus time", "the surplus labor" and "the surplus sexual intercourse" accelerated all the three ventures. The surplus time available to a male provided more time to him for entering into more sexual intercourse enhancing the chances of more pregnancies. Therefore, surplus intercourse further provided more extra-time for male to get extra-surplus hours for surplus manual activities including extra-time for intercourse. The availability of extra-surplus hour to male resulted into more pregnancies and further decrease of surplus hour of female than male, which resulted into more extra-surplus labor for male. Each pregnancy further diminished her surplus labor and increased availability of more surplus hour to male.

\footnotetext{
4“'According to Yagya (2/286), (A lawgiver of 100-300 B.C.) and Brihaspati (a law giver of 300-500 B.C.) formication even with mutual consent led maximum punishment to man if done with woman of same caste, its half punishment if done with woman of lower caste and capital punishment if done with woman of upper caste." (Dr. Pandurang Vaman Kane, 831.)
} 
More surplus pregnancy ${ }^{5}$ of female provided more surplus hour to male; and more surplus hour to him further decreased extra hour of female because of her each additional pregnancy. Each additional pregnancy further provided more extra-hour to male. The availability of surplus hour to male furthered the complexity and kinds of works. Since each innovated kind and complexity of work further diminished the significance of female. ${ }^{6}$ The availability of more extra-hour to a male made him more nomadic, more adventurous, more barbaric and more autocratic. In many of the places available extra-hour to a male gradually developed in to patriarchal human societies. It was patriarchy, which originated as the first stage of authority to rule. Indeed, its origin though was not natural but historically reliant and in no way was the result of any conspiracy of the male, as mentioned by many Anthropologists. The future of even female dominated groups where matriarchy was evolving was not secured because of unavailability of extra-hour; and gradually those few groups also became patriarchal. There originated dominance of patriarchy everywhere because of his extra-time and extra-labor by itself.

Manufacture of iron commenced during the upper status of barbarism, which ended with the invention of phonetic alphabet and use of writing in literary composition. Its termination provided commencement of civilization. Homer's Greek civilization, pre-Roman empire of Italian tribes and German tribes of the time of Caesar in Western hemisphere and Egyptian, Mesopotamian and Indus civilization in the Eastern hemisphere were the times of lower status of civilization.

By the commencement of this period human race learnt making of pottery, wooden homes, wooden boats, wandering in ocean and river for fishing, hunting for food gathering and entertainment, plantation and cattle rearing. Examples of beginning of villages also are available during upper stage of barbaric period. Status of female was considerably declined until humans reached this stage of development. ${ }^{7}$ This is the reason because of which examples of hunter female in this period is not available. Authority to rule was centralizing around male alone

\footnotetext{
5“The data we have to work from are a combination of fossil and archeological materials, knowledge of living nonhuman primates, and knowledge of living humans. Since we assume that the protohominid ancestors of Homo sapiens developed in a continuous fashion from a base of characteristics similar to those of living nonhuman primates, the most important facts seem to be the ways in which humans differ from nonhuman primates, and the ways in which we are similar. The differences are as follows: longer gestation period; more difficult birth; neoteny, in that human infants are less well developed at birth; long period of infant dependency; absence of body hair; year-round sexual receptivity of females, resulting in the possibility of bearing a second infant while the first is still at the breast or still dependent; erect bipedalism; possession of a large and complex brain that makes possible the creation of elaborate symbolic systems, languages, and cultures, and also results in most behavior being under cortical control; food sharing; and finally living in families." (Sally Slocum, 1975: pp. 39-40).

6"The females were more burdened with dependent infants and could not follow the rigorous hunt. Therefore, they stayed at a 'home base,' gathering what food they could, while the males developed cooperative hunting techniques, increased their communicative and organizational skills through hunting, and brought the meat back to the dependent females and young. Incest prohibitions, marriage, and the family (so the story goes) grew out of the need to eliminate competition between males for females." Sally Slocum, 1975, in Reiter, Rayna R. ed, 41.
} 
by the termination of barbaric period because of her negligible role in inter-tribal battles due to the historically reliant fact of "surplus pregnancy". The frequent inter-tribal battles were if making female more and more dependent upon male these battles were also promoting growth of the tradition of slavery throughout the human societies of the planet earth. Defeat in those battles was symbol of growing subjugation and subjugation was the symbol of growing authority to rule. The female subjugation was not the result of those battles. Those were only responsible for the development of the sense of her essential dependence upon male for her security. Those battles resulted into both male and female into victor and defeated (subjugated) individuals. Defeated male and the defeated female both were enslaved simultaneously and their victors also included both male and female. Female became both victor and slave without taking part in those battles. Her fate became dependent upon fate of male and his ability and capacity to fight in a battle. In the prehistoric paintings of battle scenes absence of female is a convincing proof that even female of female dominated tribes did not took part in such battles. In fact, such inference is not conclusive. It is also possible that further researches may unearth such paintings in coming future. It is also possible that male of female dominated tribes overpowered the female with the help of his surplus labour and taken the responsibility of battles over themselves. Significance of female in such tribes must have diminished very gradually.

The inter-tribal wars of barbaric period, which was responsible for origin of slavery also transformed female into weak and dependent individual and an entity made for sexual exploitation alone. Gradually, the preference for male succession commenced becoming order of the day during the state of barbarism itself. It also promoted denial of sexual freedom of female and her becoming of an entity of sexual exploitation by male, which ultimately terminated her natural right to say "no".

Then, how female commanded respect? In fact, such respect of female was only available to female of victorious tribe. Together with this female in general was respected for her natural quality of delivering a child. During those times, like earth was worshipped for its quality of producing regularly crops and eatable staples, female was worshipped for producing child. Likewise fertile plantations were worshipped, rivers were worshipped for providing water, mountains for security from enemy tribes and also vagina and male phallus for its capacity of progeny. It doesn't mean that there was matriarchy or female had authority to rule. It is to be noted that both the sexual organs were worshipped by both the sexes. It should be also kept in mind that those respect were reserved for female of victorious tribe and not for enslaved female; and even female of victorious

\footnotetext{
${ }^{7}$ Engels wrote: "Division of labour was a pure and simple outgrowth of nature; it existed only between the two sexes. The men went to war, hunted, fished, provided the raw material for food and the tools necessary for these pursuits. The women cared for the house, and prepared food and clothing; they cooked, weaved and sewed. Each was master in his or her own field of activity; the men in the forest, the women in the house. Each owned the tools he or she made and used: the men, the weapons, and the hunting and fishing tackle, the women the household goods and utensils." (Engels, 1948)
} 
tribe had no freedom to had sex with male of her choice. Invention of phonetic alphabet, and use of writing in literary composition commenced during the lower status of civilization.

All those tribes of Homo sapiens were not necessarily in the stage of promiscuity. It depended upon the population ratio of male and female in the groups. The groups with dominant number of female had possibilities of developing into a polygamous group while possibilities of developing into a polyandrous would be more in male dominated groups. Such possibilities were also dependent upon death rates also like Dadra and Nagar Haveli in India, which is still female dominant. Such differentiation was much greater in different places of the planet earth. Such discrepancies were only responsible in determining the kind of sexual behavior of the group and not responsible for deciding the authority of the rule that which sex will have the authority of rule. The authority of rule was determining gradually on the basis of the division of labour developing in the group. A male did work for say more than seventy years in total life span of hundred years while a female worked not more than say thirty-forty years in her life. She wasted such surplus hours in surplus pregnancies delivering children and child rearing. Since birth control was not known there was seldom a period in a female's life between fourteen to fifty years when she was neither pregnant nor rearing a child. On the basis of such assumption human groups may be divided into three groups during prehistoric times. Male Dominated Groups: The number of male in such groups was far more than female, where only polyandrous kind of sexual behavior was a possibility. Female Dominated Groups: The number of female in such groups was far more than man, where only polygamous kind of sexual behavior was a possibility. Equitable Sex Groups: There was no major difference in the population ratio of male and female in such groups. All three kinds of sexual relationships-polygamous, polyandrous and monogamous were present in equitable sex groups. The first two kinds of groups-male dominated and female dominated were not more. Both of them grew in very few places of some different continents. Only equitable groups developed at most of the places. The possibility of development of matriarchal groups on the basis of population ratio of such groups was confined in female dominated groups alone. In other two kinds of group growth of matriarchal authority of rule was almost impossible. In all the equitable groups in which population of both the sexes were almost equal male was gradually becoming more important because availability of his surplus labor.

"The study of the history of primitive society, on the contrary, reveals to us conditions in which men live in polygamy and their wives simultaneously in polyandry, and the common children are, therefore, regarded as being common to them all; in their turn, these conditions undergo a whole series of modifications until they are ultimately dissolved in monogamy." (Engels, 1948: pp. 31-32) 
By the commencement of lower status of civilization social status of female was degraded to the limit that a custom of female infanticide had became popular in many human societies of the world. First historical reference of female infanticide is found in 1200 B. C. Chinese texts of oracle bones. ${ }^{8}$ (Yuval Noah Harari, 2011: p. 162) Besides China, first historical reference of female infanticide in India during pre-historical times is also available in religious scriptures like one written by Aapastambha around 500 B.C. (Kane, 1992) $)^{9}$. Though, infanticide was theologically condemned by many religious scriptures, religious codes and $\mathrm{Pu}$ ranas, yet there is no reference available in the early colonial documents of state intervention to prohibit such a unified wave of mass murder. (P. K. Srivastava, 2014: pp. 269-284)

By the arrival of the period of civilization above historical process became very complicated and the female despite being equally capable of delivering all kinds of performance like male ultimately became ruled and an entity for sexual exploitation. She was kept sidelined from state rights and all kinds of political authority. Only son was entitled to become ruler. Even during age of savagery and barbarism the chief of tribes were mostly the most powerful and able male. Almost all surviving female dominated tribes were also become extinct or were becoming extinct by the end of barbaric period. In due course even all kinds of administrative responsibilities were entrusted to local powerful male or victors alone. The historical process commenced through "surplus labor" was therefore completed and female kept on missing all kinds of sources of authority. The few examples of woman rulers found in history were only special circumstances in which women succeeded fathers or husbands because of unavailability of able male successors to keep the purity of blue blood or royal blood. ${ }^{10}$ Even in such circumstances the successors of such daughters or wives were her sons alone and

${ }^{8}$ Harari wrote: “On one (oracle bone) was engraved the question: 'Will Lady Hao's childbearing be lucky?' 'To which was written the reply: 'If the child is born on a ding day, lucky; if on a geng day, vastly auspicious.' However, Lady Hao was to give birth on a jinyin day, The text ends with the morose observation:' 'Three weeks and one day later, on jiayin day, the child was born. Not lucky. It was a girl.' (Houston, First writing, 196) More than 3,000 years later, when Communist China enacted the 'one child' policy, many Chinese families continued to regard the birth of a girl as a misfortune. Parents would occasionally abandon or murder newborn baby girl in order to have another shot at getting a boy." (Yuval Noah Harari, 2011: p. 162).

${ }^{9}$ Srivastava wrote: The religious sanction behind the customary belief, in preference for male child to a female child has remained instrumental for female infanticides since time immemorial. The motherhood of widows and unwed virgins was considered an act of sin. Many Hindu scriptures declared infanticide as one of the serious sins to be stringently punishable. A scripture by Aapastamb$h a$, provided sometime between 400 and $600 \mathrm{BC}$, considered it a grave sin. (Dr. Pandurang Kane, 1992) Axiomatic, as it was also an evidence of prevalence of the custom in ancient India in spite of its being an act of sin. The distinction between infanticide and female infanticide is altogether lacking in Hindu religious texts but the enormity of female infanticide as conformed by documentary evidences of colonial India are living testimony of its presence in pre-colonial India. Pramod Kumar Srivastava, "Female Infanticide in $19^{\text {th }}$-Century India: A Genocide?" Advances in Historical Studies, 3, (2014) 269-284. https://doi.org/10.4236/ahs.2014.35022

${ }^{10}$ Tomyris became queen of Massagetae after death of her husband. Massagetae was the race, which occupied the plain in the east of Caucasus during the Greek campaign of Cyrus, the Emperor of Persia (Herodotus, 1948: pp. 89-90). 
not daughters. This tradition is still surviving in many societies of the world in which real authority to rule is only surviving in the hands of man, whether democratic, socialist or communist.

\section{Conclusion}

Still in many civilized societies of the human world, woman has no right to say "yes" or "no" to a sexual proposal proposed by a man. The naturalization of denial of such rights available to man alone ultimately became mainstream of all other kinds of denials to women, right to property, right to divorce, right to vote, right to head religious orders, right to sovereignty, right to choose professions, right to lead tribes etc., or all such rights available to man alone may be also defined as patriarchy, besides "father as head of the family, tribe or society". Indeed, women regained such historically reliant rights in many societies of the modern human world but of course not earlier than the nineteenth century. Indeed, in a number of human societies said to be uncivilized, women were not denied right to choose or reject sexual partner, but no civilized human world till advent of nineteenth century allowed women to enjoy such rights. Indeed, in many tribal societies of antiquity, during the age of savagery and the age of barbarism before invention of the knowledge and practice of agriculture, women were said to be enjoying precedence over man about such rights. However, with the commencement of historical phenomenon of inter-tribal battles and surplus labor of male and surplus pregnancy of female during savagery and barbarism initiated subjugation of female, it continued until nineteenth century invention of the science of family planning, right of termination of unwanted pregnancies and commencement of the demands of the right of divorce, right of selection of male and the aspiration of the political right of suffrage, historical denial of which commenced during the stages of savagery and barbarism.

\section{Acknowledgements}

I sincerely acknowledge the role my late friend Late Mr. Krishna Murari Lal, who was primarily responsible for instigating and shaping my thought process. He did his post-graduation from my Department of Western History, University of Lucknow, around a decade before I did. I presented the basic idea of this article related with "Victor male and victor female, and defeated man and defeated women in Inter-Tribal Wars and the idea of Surplus labour and surplus pregnancy" in a paper, entitled "Women Liberation Movement" on 29-9-1984, in a meeting of Saturday School of Young Thoughts, a philosophical society meeting every Saturday evening, at his residence in Mahanagar, Lucknow, U.P., India.

\section{Conflicts of Interest}

The author declares no conflicts of interest regarding the publication of this paper. 


\section{References}

Collingwood, R. G. (2015). The Idea of History (Revised Edition with Lectures 1926-1928, Edited with an Introduction by Jan Van Der Dussen). Oxford University Press.

Coontz, S. (2005). Marriage, a History: How Love Conquered Marriage. Penguin Books.

Engels, F. (1948). The Origin of the Family, Private Property and the State: In the Light of the Researches of Lewis H. Morgan. Progress Publishers.

Herodotus (1954, 2003). The Histories. Translated by Aubrey De Selincourt, Revised with Introduction and Notes by John Marincola, Penguin Books.

Harari, Y. N. (2011). Sapiens: A Brief History of Humankind (p. 162). Vintage Books.

Kane, P. V. (First Edition, December 1965, Fourth Edition, June 1992). Dharmshastra Ka Itihas (Hindi) (Pracheen evam Madhyakaleen Bhartiya Dharm tatha Lok-vidhiyan: Bhag Second, Uttar Pradesh Hindi Sansthan, Lucknow-226001 [Ancient and Medieval Indian Religion and Folk Laws, Translator Arjun Chaube Kashyap (Vol. 2).

Morgan, L. H. (1877). Ancient Society: Or Researches in the Lines of Human Progress from Savagery through Barbarism to Civilization. Charles H. Kerr \& Company.

Reiter, R. R. (1975). Towards and Anthropology of Women. New York and London: Monthly Review Press.

Webster, P. (1975). Matriarchy: A Vision of Power. New York and London: Monthly Review Press.

Ritchie, D. A. (2003). Doing Oral History: A Practical Guide. Oxford University Press.

Slocum, S. (1975). Woman the Gatherer: Male Bias in Anthropology. In R. R. Reiter (Ed.), Toward an Anthropology of Women. Monthly Review Press.

Srivastava, P. K. (2014). Female Infanticide in 19th-Century India: A Genocide? Advances in Historical Studies, 3, 269-284. https://doi.org/10.4236/ahs.2014.35022

Thucydides (1972). History of the Peloponesian War. Translated by Rex Warner with an Introduction and Notes by M.I. Finley, Penguin Books. 